thétique bouchère, si ce dernier classement demeure inchangé, en croisement avec des mâles Limousins et Blonds d'Aquitaine, en Charolais toutefois les races laitières de grand format comme la Pie-Rouge de l'Est, la Brune des Alpes et la Normande permettent une meilleure expression du potentiel de croissance de ces mâles.

Ces résultats indiquent notamment que la valorisation des races comme femelles allaitantes support d'un croisement avec des races à viande, implique la recherche d'une complémentarité entre les composantes maternelles des premières et directes des secondes, en vue d'obtenir un équilibre optimum entre le format, les caractères de croissance (potentiel de croissance, production laitière) et la conformation.

\title{
APTITUDE A LA GÉMELLITTÉ DES RACES A VIANDE FRANÇAISES : OBSERVATIONS EN ÉLEVAGE ET CONSTITUTION D'UN TROUPEAU DE SÉLECTION
}

\author{
F. Ménissier, J. Frebling. - Département de Génétique animale, C. N. R. Z., 78350, Jouy en \\ Josas (France).
}

Du fait des récents progrès dans les techniques de reproduction et de l'existence d'une variabilité d'origine génétique de la fréquence des vêlages gémellaires, il est envisageable d'accroître par sélection le taux de gémellité chez les bovins de races à viande.

A partir des informations collectées en ferme lors du contrôle national de croissance des bovins, nous avons estimé la fréquence des naissances gémellaires dans les races à viande françaises en fonction du rang de vêlage des mères et de la saison : cette fréquence est environ 7 fois plus élevée en Maine-Anjou (3,8 et 5,3 p. I0o) qu'en Limousine $(0,5-0,8$ p. 100) ; la Charolaise $(3,2-3,4$ p. 100) et la Blonde d'A quitaine (1, I-0,9 p. roo) ont des fréquences intermédiaires. Ces résultats confirment nos précédentes observations où nous avions noté des différences entre régions et une certaine répétabilité entre années du taux de veaux jumeaux des grands élevages. A cette occasion, nous avions aussi constaté que, si la fréquence des couples de jumeaux monozygotes parmi l'ensemble des couples de jumeaux diminue avec l'âge des mères, leur fréquence absolue rapportée à l'ensemble des vêlages reste faible $(0,4 \mathrm{p}$. Ioo) et peu variable avec le rang de mise bas des mères.

Dès 197 I-I 972 nous avons rassemblé dans un même troupeau des vaches ayant eu naturellement 2 à 5 fois des veaux jumeaux. Ces 2 I Maine-Anjou et 18 Charolaises constituent le troupeau de femelles fondatrices que nous avons exploité durant 3 années en race pure, 48 et 41 p. Ioo respectivement de leurs mises bas dans leurs élevages d'origine, avaient donné naissances à des veaux jumeaux.

Après ces 3 années, I 9 couples de jumeaux sont nés (32 p. roo des vêlages). A la suite des premiers vêlages observés dans le troupeau, mais résultant des fécondations dans les élevages d'origine des vaches fondatrices, 44 p. Ioo des Maine-Anjou et I2 p. Ioo des Chavolaises ont engendré des veaux jumeaux. En ne considérant que les fécondations obtenues dans le troupeau, 24 et 36 p. Ioo des vêlages de ces races respectivement ont produit des veaux jumeaux. Parmi les 28 premières fondatrices exploitées durant deux campagnes dans les mêmes conditions, 7 (25 p. 100) ont à nouveau donné au moins une fois des jumeaux. Si nous rassemblons toutes les performances des vaches fondatrices, il ressort alors que 23 p. Ioo d'entre elles ont eu naturellement au moins 4 paires de jumeaux.

Ces premiers résultats sont encourageants. La poursuite de ce travail nécessite, d'une part la recherche de critères précoces prédicteurs de l'aptitude à la gémellité et, d'autre part, le recours aux techniques de superovulation et transplantation d'œufs. C'est dans de telles conditions que nous allons tenter de préciser les modalités d'application d'une sélection efficace sur l'aptitude à la gémellité.

\section{WIRTSCHAFLICHE AUSWIRKUNGEN DER EINKREUZUNG} VON HOLSTEIN-FRIESIANS IN DEUTSCHE SCHWARZBUNTE RINDER

\section{E. ERNST. - Institut für Tierucht und Tierzhaltung, Universität Kiel (BRD).}

Die Einkreuzung von Holstein-Friesians in deutsche schwarzbunte Rinder hat die Ausgangspopulation der deutschen Rinder verändert. $F_{1}$-Tiere und Deutsche Schwarzbunte unterscheiden sich in wichtigen Merkmalen signifikant. $F_{1}$-Tiere übertreffen die deutschen Schwarzbunten im Gewicht um 6 Prozent in der Widerristhöhe um 4 Prozent in der Milchleistung um 13 Prozent 
(= Durchschnitt von Feld-und Versuchsmaterial) und im durchschnittlichen Minutengemelk um I 7 Prozent Darüber hinaus wurde das Geburtsgewicht der $F_{1}$-Kälber erhöht. Bei Mastbullen führte eine geringere Fleischfülle bei $F_{1}$-Bullen zu einer schlechteren Bezahlung als bei Mastbullen reinrassig deutscher Herkunft (- - , Io DM/kg Lebendgewicht).

Wenn die Verwendung von $H F$-Bullen in der deutschen Schwarzbuntzucht ökonomisch sinnvoll sein soll, dann muss die Steigerung der Milchleistung die aufgetretenen und ökonomisch bedeutenden Nachteile dieser Zuchtmassnahme (höherer Nährstoffbedarf für Erhaltung und Foetusausbildung, schlechtere Bezahlung von Mastbullen) mehr als nur ausgleichen.

Uber Berechnungen von Deckungsbeiträgen ergab sich, dass bei einer Mehrleistung von rd. ro $\mathrm{kg}$ FCM je $\mathrm{kg}$ höheres Lebendgewicht eine Wettbewerbsgleichheit zwischen $\mathrm{F}_{1}$-Kühen ( $H F \times$ $D S B)$ und Deutschen Schwarzbunten gegeben ist. Wird diese Differenz zugunsten der $F_{1}$-Tiere überschritten, dann ist die Einkreuzung ökonomisch sinnvoll.

\title{
GeNETIC EVOLUTION OF CATTLE FOR BEEF PRODUCTION IN NEW ZEALAND
}

\author{
A. H. CARTER. - Ministry of Agriculture and Fisheries, Ruakura Animal Research Station, \\ Hamilton (New Zealand).
}

Although the trials reported vary widely in design, in genetic sampling and environmental conditions and hence in the generality of their findings, the following conclusions seem warranted in the New Zealand farming situation.

i) Relative to the Angus, the Friesian produces 20-30 p. Ioo more and the Hereford 5-10 p Ioo more final liveweight and carcass weight when slaughtered off pasture at 1 8-22 months of age. Approximately half this superiority is manifested in corresponding Angus crosses.

ii) In terms of weaning performance the Friesian dam is greatly superior, the Hereford slightly inferior, to the Angus.

iii) Heterosis in growth rate is of the order of $5 \mathrm{p}$. Ioo in crosses among the Angus, Hereford and Friesian.

iv) Dairy and dairy $\times$ beef breed carcasses contain proportionately more bone and consequently less meat than those from British beef breeds. Differences in dressing percentage are not consistent but tend to favour the beef breeds.

v) As a crossing sire for meat production from Jersey cows, the Charolais is superior to the Hereford but not significantly better than the Friesian, despite its higher lean meat yield.

Further information is needed on the lifetime calf production efficiency of the Friesian and Friesian-cross cow under hill country conditions and on the merit of Charolais crosses in suckler beef herds. Very preliminary results suggest that some of the other large European breeds may have potential in improving beef productivity from both dairy and suckler herds. Efficient exploitation of breed resources - through breed substitution, synthesising of new breed combinations or systematic crossbreeding-clearly demands more detailed knowledge of general and specific combining abilities. Effective oestrous control in beef herds will facilitate artificial breeding and so permit realisation of the benefits and flexibility of crossbreeding systems.

A consistent finding in those experiments where sires were identified has been the wide range in progeny performance of individual sires within breeds, usually greater than breed differences themselves. This pinpoints the very great importance of sound selection on performance merit, whatever the breed or breeding system.

\section{POSSIBILITY OF ESTIMATING HETEROSIS}

\section{WHEN THE EXTRANEOUS BREED IS IMPORTED BY MEANS OF SEMEN}

\section{E. A. Fimland. - Agricultural University of Norway, Aas-NLH, Norway.}

Exchanging deepfrosen semen may be a valuable tool for utilizing different breeds as potential breeding resources.

Imported semen of dairy bulls of extraneous breeds can be utilized as follows :

I. Importation of positive genes for further additive breeding work.

2. Enhancing the producing ability of the native population by means of exploiting any effect of heterosis. 